\title{
Epidemiology of Amyotrophic Lateral Sclerosis
} Amyotrofik Lateral Skleroz Epidemiyolojisi

\author{
(1) Mehmet Rifk1 Aktekin1, (1) Hilmi Uysal2 \\ ${ }^{1}$ Akdeniz University Faculty of Medicine, Department of Public Health, Division of Epidemiology, Antalya, Turkey \\ 2Akdeniz University Faculty of Medicine, Department of Neurology, Antalya, Turkey
}

\begin{abstract}

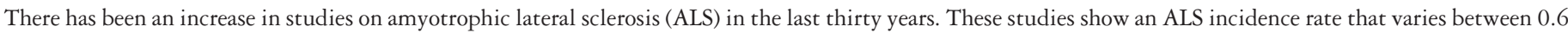

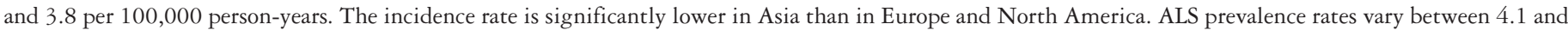

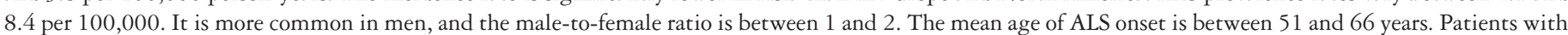

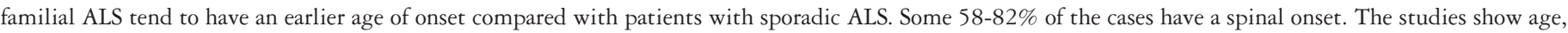

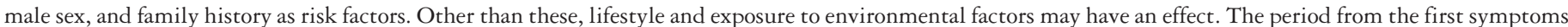

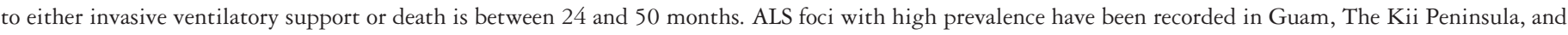

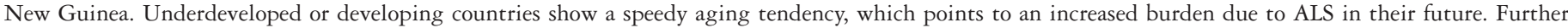
epidemiologic studies with higher case numbers in different regions are needed to be able to enlighten causative associations of the disease.
\end{abstract}

Keywords: ALS, rare diseases, epidemiology, motor neuron diseases

Öz

Amyotrofik lateral skleroz (ALS) konusunda yapılan çalışmalar son 30 yıl içerisinde hız kazanmıştır. Bu çalışmalarda ALS insidansı yüz binde 0,6 ile 3,8 (kişi-yıl) arasında değişen oranlarda bulunmuştur. İnsidans Asya ülkelerinde Avrupa ve Kuzey Amerika'ya göre belirgin olarak düşüktür. Hastalık prevalansı yüz binde 4,1 ile 8,4 arasında değişmektedir. Erkeklerde daha sık görülmekte olup erkek/kadın oranı 1 ile 2 arasında yer almaktadır. Ortalama başlangıç yaşı 51 ile 66 arasındadır. Ailesel ALS olgularında hastalık, sporadik ALS olgularına göre daha erken yaşta başlama eğilimindedir. Olguların \%58-82'si spinal başlangıçlıdır. Yaş, erkek, cinsiyet ve aile öyküsü gösterilebilmiş risk faktörleridir. Bunun yanında yaşam tarzı ve çevresel maruziyetlerin etkisi söz konusu olabilir. Belirtilerin başlangıcından ölüme veya invazif solunum desteğine kadar geçen süre 24 ile 50 ay arasındadır. Dünyada Guam, Kii yarımadası ve Yeni Gine'de yüksek prevalanslarla karakterize hastalık odaklarına rastlanılmıstır. Az gelişmiş ve gelişmekte olan ülkelerde nüfusun hızlı bir yaşlanma eğilimine girmesi gelecek yıllarda ALS'nin oluşturduğu hastalık yükünün giderek artacă̆ını düşündürmektedir. Hastalığın nedensel ilişkilerinin aydınlatılabilmesi için değişik bölgelerde, yüksek olgu sayılarına sahip epidemiyolojik çalışmalara gereksinim vardır.

Anahtar Kelimeler: ALS, nadir hastalıklar, epidemiyoloji, motor nöron hastalıkları

\section{Introduction}

Amyotrophic lateral sclerosis (ALS) is a progressive neurodegenerative disease affecting the cortical, brainstem, and spinal cord motor neurons of the central nervous system. As a part of the motor neuron disease group, it is known as an adult age group disease with clinical signs of upper and lower motor neurons, poor prognosis and no treatment. Although the first descriptions of the disease go back to 1824 and Charles Bell (1774-1842), the links between disease symptoms and underlying causes were first described by Jean-Martin Charcot (1825-1893), who is often described as the father of neurology. It has been called ALS since 1874 (1). Charcot included this definition in his book "Oeuvres Completes", published in 1874. In discussing the developments in the disease, it would be unfair not to mention Charcot's colleagues

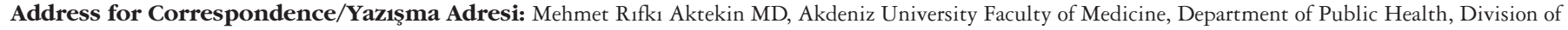
Epidemiology, Antalya, Turkey

Phone: +90242 2496944 E-mail: mehmetaktekin1@gmail.com ORCID: orcid.org/0000-0002-0745-9194

Received/Geliş Tarihi: 18.03 .2020 Accepted/Kabul Tarihi: 29.06.2020

${ }^{\circ}$ Copyright 2020 by Turkish Neurological Society

Turkish Journal of Neurology published by Galenos Publishing House. 
Jean Cruveilhier (1791-1874), Alix Joffroy (1844-1908), and later William Richard Gowers (1845-1915) for their great contribution to understanding motor neuron disease. ALS is also referred to as Lou Gehrig's disease, following the diagnosis of Lou Gehrig, the famous player of the New York Yankees baseball team in 1939. Lou Gehrig was one of the most famous baseball players of his era. It was observed that his strike power gradually decreased, despite the perfect timing during the hit. A definitive diagnosis could not be made in preliminary examinations in New York. He was then hospitalized and examined for a week at the Mayo Clinic in Minnesota. A diagnosis of ALS was made by Dr. Harold Habein. Lou Gehrig was aged 36 years at the time. The Mayo Clinic included the following statements in the epicrisis given to him on his birthday: "Following a careful and thorough examination, Mr. Gehrig was found to be suffering from ALS. This disease involves motor tracts and central nervous system cells and is known as a form of chronic poliomyelitis (infantile paralysis)". In the middle of May 1941, Gehrig's respiratory distress reached its final stage. He lost consciousness on June 2 and died at the age of 37 on the same night (2).

\section{Incidence}

Recent studies have shown that the incidence of ALS varies between 0.6 and 3.8 per 100,000 using the person-year calculation method $(3,4,5,6,7,8,9,10,11)$. Longinetti emphasized that the incidence of ALS in the European continent ranged from 2.1 to 3.8 per 100,000 (person-year) $(3,4,5,9,11)$, whereas Logroscino showed that the incidence according to the results of populationbased studies for the same region ranged from 1.7 to 2.3 per 100,000 (person-year) (12). The incidence rates of ALS in some countries are listed in Table 1 . The highest incidence rates were obtained in Swedish and Scottish studies.

In general, it is observed that the incidence of ALS is lower in Asian countries compared with Europe and North America. The reason for this may be demographic factors: ALS is mostly a middle and old-age disease and the density of the population at risk varies in countries. However, a controversial claim is that the prevalence of known $A L S$ genes in Asian countries is low $(13,14)$. In addition to geographic differences, many studies examining the change of ALS incidence over the years drew attention to the fact that the incidence had increased gradually $(5,7,9)$.

On the other hand, for example, registry centers in Europe can catch around 60-100 new cases every year due to the rarity of

\begin{tabular}{|lcc|}
\hline $\begin{array}{l}\text { Table 1. Amyotrophic lateral } \\
\text { detected in different regions }\end{array}$ & sclerosis incidence rates \\
\hline Region & Year & $\begin{array}{c}\text { ALS incidence } \\
\text { (100,000 person-years) }\end{array}$ \\
Stockholm (3) & 2014 & 3.8 \\
Scotland (9) & $2015-2017$ & 3.8 \\
Norway (5) & $2000-2015$ & 2.1 \\
Italy (4) & $2002-2014$ & 2.8 \\
South Korea (6) & $2011-2015$ & 1.2 \\
China (8) & $2010-2015$ & 0.8 \\
Thrace (7) & $2006-2010$ & 1.9 \\
ALS: Amyotrophic lateral sclerosis & \\
\hline
\end{tabular}

the disease. Larger sample sizes are needed to answer some of the complex questions about the disease, for example, to explain the changes caused by aging or why the incidence begins to decline from the age of 75 years. Similarly, it is necessary to work with a large number of patients from different regions to determine the environmental risk factors associated with the disease and to analyze genetic differences.

In a study in which data addressing a 24 million population in Europe in 1998-1999 were combined, the incidence of ALS was found as 2.2 per 100,000 (person-year), and 2.7 for the population aged over 18 years in 1028 patients (15). In this study, it was determined that the male/female ratio was 1.3 , and it was more clearly shown than in previous studies that the incidence decreased after the age of 75 years, especially in men, and then in women (15).

To overcome the problems arising from the lack of patients, community-based data producing registry centers in Amsterdam were gathered under a union in 2004 and took the name European Amyotrophic Lateral Sclerosis (EURALS). These regions using the same diagnostic criteria (El Escorial Criteria, EEC) were predominantly in Italy, Scotland, and Ireland. According to these data, the EURALS records of five regions showed that the ALS incidence between the ages of 45-74 years was 5.2 in Scotland, 6.0 in Ireland, 5.4 in Piemonte (Italy), 4.2 in Lombardy (Italy), and 4.1 in Puglia (Italy) (16).

There have been meta-analyses on ALS in recent years. The results of the meta-analysis conducted by Marin et al. (17) covering 45 geographic regions are presented in Table 2. Fifty percent of the countries included in the meta-analysis were performed in Europe and 30\% in North America. Latin America and Asia were represented by one or more studies. There were no data for SubSaharan Africa.

\section{Prevalence}

Recent studies show that the prevalence of ALS varies between 4.1 and $8.4 / 100,000(3,4,5,6,7,9,18)$. These studies suggest that the prevalence of ALS is slightly increased. This increase may be due to demographic changes, as well as to an increase in diagnostic opportunities and prolonging life expectancy due to improved quality of care. Nelson et al. (18) reported the prevalence of ALS as 3.7/100,000 in 2002, 4.4/100,000 in 2003, and 4.8/100,000 in 2004. On the other hand, Mehta et al. (19), using the American National ALS records, reported the ALS prevalence as 5.0/100,000 in 2014 and 5.2/100,000 in 2015. Unlike population-based studies,

\begin{tabular}{|lc|}
\hline $\begin{array}{l}\text { Table 2. Meta-analysis } \\
\text { sclerosis incidence* }(17)\end{array}$ & results of amyotrophic lateral \\
Region & Incidence $(100,000$ person-years $)$ \\
Northern Europe & 1.89 \\
Southern Europe & 1.75 \\
East Asia & 0.89 \\
South Asia & 0.79 \\
Caribbean & 1.19 \\
New Zeland & 2.29 \\
South America & 1.59 \\
"Data are standardized according to the 2010 population of the United States \\
\hline
\end{tabular}


in a sample representing the United States in 2011, Bhattacharya et al. (20) found the prevalence of ALS to be 11.8/100,000 with data based on the Medicare Advantage prescription drug plan within the healthcare advantage package of the American healthcare system. The reason why this prevalence was higher than the others might be that there was a greater proportion of elderly participants among the people included in the advantage package. Again, a study based on the data of the National ALS Registry system showed that the prevalence of ALS disease in people of European-American origin was more than twice that of African American patients (5.4 and 2.3/100,000 respectively) (19).

When the prevalence of patients with motor neuron disease is examined globally, it is seen that North America, Northern Europe, Australia, and New Zealand stand out compared with other regions (21).

Figure 1 shows the global distribution of age-standardized prevalence rates (per hundred thousand) of motor neuron diseases (21).

\section{Sex}

Male sex has been considered as a risk factor for a long time ALS (22). The male/female ratio is generally reported as between 1 and 2 in recent studies $(4,5,6,7,8,9,18,20,22,23$, 24,25). However, a report from Africa indicates that this rate is as high as 2.9 (26). According to the EURALS records, the distribution of ALS incidence rates in five regions of Europe by sex is given in Table 3 (16). Because these data were standardized for the population of the 45-74 age group, where the disease was more common in the 1990 United States population, the incidence rates seemed to be higher, although the male/female ratio was observed to vary between 1.26 and 1.90. Most recently, a study based on the Swedish Motor Neuron Disease Registry in Stockholm reported a male/female ratio of around 1 (3). It is not yet possible to claim that the male/female ratio has decreased in favor of men just by looking at these and similar results. To show the change in the ratio of men/women over time, it is necessary to

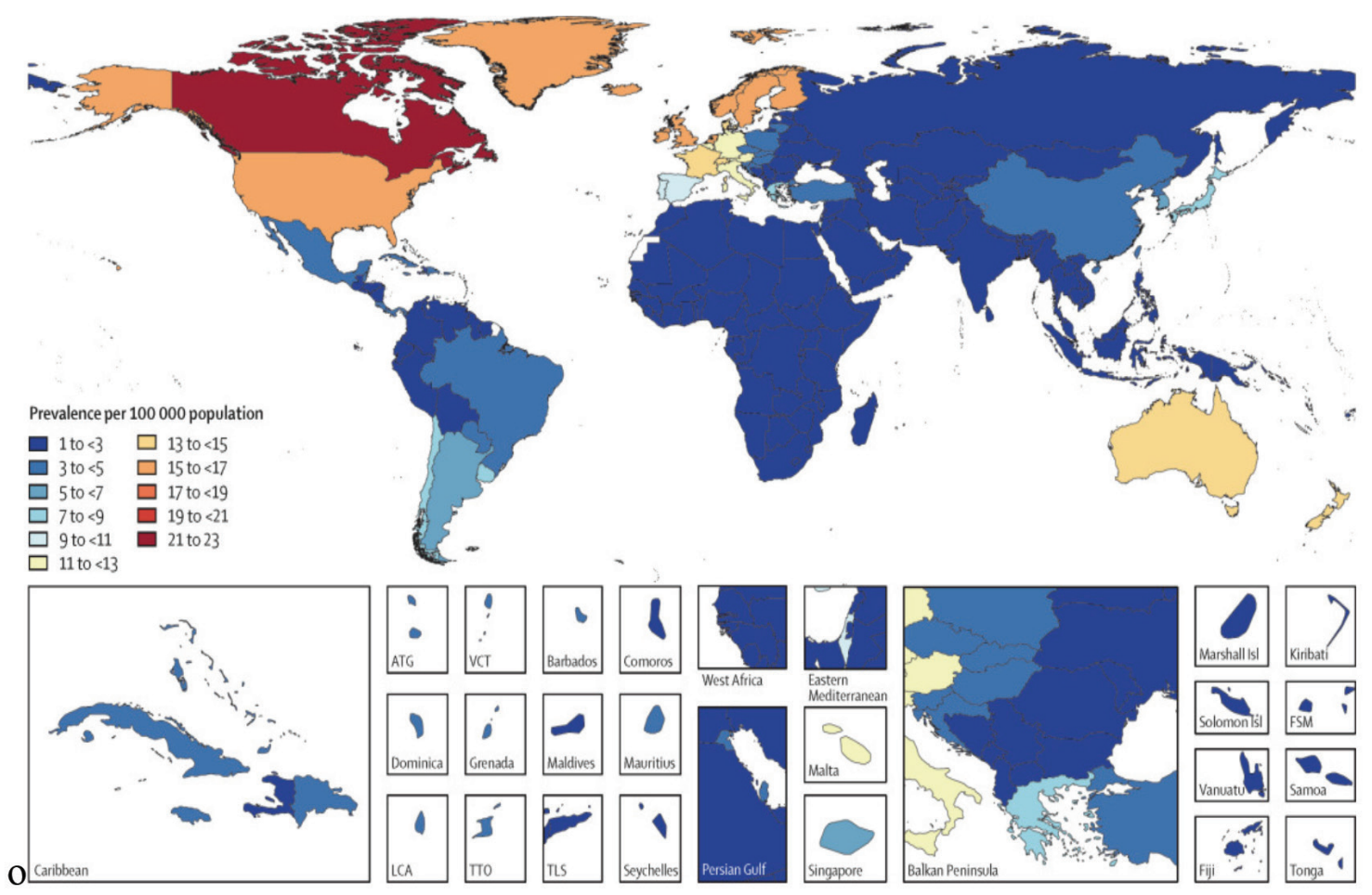

Figure 1. Global distribution of age-standardized prevalence rates (per hundred thousand) of motor neuron diseases, 2016 (21)

Table 3. Amyotrophic lateral sclerosis incidence rates in the five European ALS regions by sex* (16)

\begin{tabular}{llccc} 
Region & Years & $\begin{array}{c}\text { Incidence in males } \\
(100,000\end{array}$ & $\begin{array}{c}\text { Incidence in females } \\
(100,000 \text { person-years })\end{array}$ & Male/female ratio \\
Scotland & 1989 & 6.7 & 3.8 & 5.3 \\
Ireland & $1995-1997$ & 6.7 & - & 1.76 \\
Italy & $1995-1996$ & - & 4.7 & - \\
Piemonte & $1998-2002$ & 5.1 & 3.5 & 1.26 \\
Lombardia & $1998-1999$ & 5.5 & 2.9 & 1.46 \\
Puglia & "Incidence rates are standardized for the population of the $45-74$ age group in 1990 in the United States. ALS: Amyotrophic lateral sclerosis \\
\hline
\end{tabular}


evaluate the results of many future studies in different countries in the coming years.

\section{Age of Onset}

Recent studies suggest that the average age of onset of ALS varies between 51 and $66(3,5,6,7,8,9,25,27,28,29,30)$. When the age of onset is examined globally, it is noteworthy that there are differences between regions. For example, in patients of European descent, the age of onset is later than those reported in China, Cuba, and Uruguay. The median age of onset of ALS in China was reported as 51 years (25). On the other hand, the age of onset in German patients was approximately 10 years later (25). Another study found the average age of onset of ALS in patients in Cuba and Uruguay as 4-9 years earlier than patients in Ireland (30). When the reasons for this situation are examined, we come across several possible reasons. One is the difference between patient characteristics found in population-based studies and patient characteristics found in clinical-based studies. It is possible for patients to be diagnosed at an earlier age and the higher rate of such patients in the patient pool could reduce the mean age of onset because the immediate surroundings of a patient identified in clinical-based studies are examined due to their risk. In addition, since these patients are recognized at an early age, they may have a longer and milder progression in terms of clinical features. This leads to some differences in clinical features compared with the data obtained from population-based patients (31). European data are generally based on studies with population-based designs. Therefore, one of the reasons why the age of onset is high in European studies is that the data are population-based. Another claim is that genetic factors are effective in the early onset of ALS. Patients with familial ALS tend to have an early onset of about ten years, more than patients with sporadic disease (32,33). This finding may be due, in part, to the early diagnosis of ALS patients' disease, as symptomless relatives of ALS patients are also examined and diagnosed (34). Nevertheless, the findings of Mehta et al. (35) showed that a reason for early-onset in patients with familial ALS could be attributed to pathologic genetic variations. Although the ratio of familial patients among all patients with ALS is considered to be around $5 \%$, it is known that the number of familial patients is much higher in Northern and Western Europe (36).

Various theories and approaches have been proposed to explain the differences in the age of disease onset according to the geographic regions. According to the results of a new metaanalysis (37), the incidence of ALS reaches its highest value at the age of 71.6 years with 7.0/100,000 (person-year) in Europe. In North America, this value is between 8.2 and 77.4 years per hundred thousand. Although the age peak of the disease is 75 years in East Asia, unlike Europe and North America, the incidence rate is only 2.2/100,000. This difference indicates that the risk of disease is three-times higher in the age groups with the highest risk in the Caucasian race compared with the Chinese. One of the reasons for these geographic differences is the C9ORF72 gene, which explains the genetic differences that we have partially mentioned above (38). C9ORF72 is the best-known gene to be associated with ALS and accounts for $40 \%$ of familial patients and $8 \%$ of sporadic patients in European and North American societies (39). On the other hand, the prevalence of the C9ORF72 gene mutation in patients with ALS is less than $4 \%$ (40) in the East (Japan), $5.9 \%$ in familial patients in South Asia (Iran), and
$1.6 \%$ in sporadic patients (41). In Asian countries, it is accepted that this gene is not one of the major causes of ALS. By contrast, the prevalence of C9ORF72 mutations was found to be very high in Finland. Finland is also one of the countries with the highest incidence of ALS in the world (42). It was predicted that the gene mutation emerged in Scandinavia 1500 years ago, it spread from Scandinavia to Europe and North America with Viking migration, and countries such as Australia and New Zealand, mainly through economic migration from those regions in the last few centuries. The frequency and age distribution map of the disease and this migration scheme, including the gene, match each other (21).

\section{Delay in Diagnosis and Age of Diagnosis}

ALS is easy to diagnose but needs to be confirmed. The precursor symptoms of ALS are generally not specific to this disease and may mimic other neuromuscular diseases. These diseases are often called mimic syndromes. Diagnostic errors in the early period may delay the diagnosis of ALS. In addition, valid diagnostic biomarkers are not sufficient (43). The diagnosis of ALS is made clinically and it takes time to demonstrate that its symptoms spread progressively (44). Recent studies show that the delay in diagnosis varies between 9 and 24 months in terms of average or median $(3,4,5,6,7,8,9,26,27,45)$. The familial form of the disease (35), initial involvement site, and sex can be listed among the factors that cause a delay in diagnosis. For example; as far as determined in patients residing in Beijing; it may be possible to diagnose earlier in bulbar-onset patients than in spinalonset patients, and in males than in females (8).

When the latest studies are evaluated, the mean or median age at diagnosis ranges between 54 and 69 $(3,4,5,6,7,8,9,23,27,28,30,45)$. Age at diagnosis varies according to the presence of cognitive impairment and sex. The mean age at diagnosis is eight years higher in patients with cognitive impairment compared with others (23). Again, in a study conducted in North-East Italy, the average age of diagnosis in women was found to be slightly higher than in men (4). When the Far-East was examined, a similar result appeared in Japan (46), but no difference was found between men and women in a clinical study conducted in Beijing (8).

\section{Site of Onset}

ALS usually occurs with weakness in the extremities, i.e. spinal onset, or with difficulty speaking and swallowing, i.e. bulbar onset. In various studies, it has been shown that patients have spinal onset at rates varying between $58 \%$ and $82 \%$ $(3,4,7,8,9,25,26,27,30,45,46)$. It is seen that these rates are quite consistent when different countries are examined. In various studies, it has been found that the spinal onset rates of the disease are at similar levels, with no statistically significant difference, for example between the Chinese and German populations (25), or between Cuba, Uruguay, and Ireland (30). Although spinal onset is more common worldwide, bulbar-onset ALS can be seen at different frequencies among patients with different characteristics. For example, bulbar onset rates are higher in female patients with ALS $(3,4,8)$, patients with ALS and cognitive impairment (23) and elderly patients (8) compared with male patients, patients without cognitive impairment, and younger patients. A study conducted in South-East England found a significant relationship between 
onset of symptoms at advanced ages, female sex and bulbar onset (47). Again, for example, when patients over the age of 70 are examined, it is seen that the rate of bulbar onset reaches $43 \%$, but this rate is only around $15 \%$ in patients under 30 years $(16,48,49)$. On the other hand, bulbar onset rate was found to be similar with $27 \%$ and $28 \%$ among European-American and African-American patients (50). Recent studies have shown that in addition to spinal or bulbar onset, there may be some different forms of onset at rates varying between $8 \%$ and $23 \%(3,4,9,51,52)$. These are spinal and bulbar mixed onset (4,9), thoracic onset (52), onset with respiratory system symptoms and respiratory weakness $(9,53,54)$ or cognitive changes (9) or a combination thereof $(3,45)$.

\section{Risk Factors}

Risk factors that have been confirmed to date are age, male sex, and family history. A growing body of evidence suggests that smoking should also be considered as a risk factor. Nevertheless, it has not been shown that many of the risk factors claimed to be related to ALS have a causal nature. Statistical relationships have been determined between many factors and ALS, and some were found to conflict with each other when causality criteria were taken into account. For this reason, while evaluating the risk factors of ALS, research results should be approached with caution, and it should be kept in mind that research with more patients, with secure patterns and common recording systems are needed to determine the real relationships. In this sense, the "possible" risk factors identified in the studies so far, which will be listed below, should be evaluated with this understanding.

Most epidemiologic studies have focused on various possible risk factors such as lifestyle, body mass index (BMI), education level, exposure to toxic substances, viral infections and comorbid conditions $(22,55,56,57,58,59,60,61)$. In addition to tobacco use, alleged causal relationships between some of these risk factors and the disease have been identified. Examples of these include blood lipid levels $(58,62)$, physical activity (58), and education level (58). Military service, agriculture, jobs requiring heavy bodily effort, forestry, fishing, hunting, construction work, plastic industry, welding and soldering works, athletics, American football as an occupation; and pesticides, mercury, lead, aluminum, trauma, electric shocks, exhaust gases, sodium silicate, organic dust, air pollution and low-frequency magnetic fields as exposure have been found to be associated with ALS in various studies (11). Another issue of interest is dietary habits. Pupillo et al. (45) found evidence that certain nutrients and food molecules increased the risk of ALS. These were red and processed meat and meat products, animal proteins, sodium, zinc, and glutamic acid. The same study, however, suggested that certain foods, such as coffee, tea, whole wheat bread, raw and unprocessed vegetables, and citrus fruits, were likely to reduce the risk of ALS. To date, no relationship has been found between alcohol consumption and ALS $(45,52)$.

Concerning physical activity, a large cohort study of Swedish men found that low muscle strength, low BMI, and low erythrocyte volume fraction increased the risk of ALS (63). One unit increase in BMI and erythrocyte volume fraction led to a lower risk of ALS. Again, low muscle strength increased the risk of ALS 1.4 times in the later periods of life when compared with high muscle strength (63).

\section{Genetic Factors}

Although it has been reported that an increasing number of genes affect the formation of ALS (64), the role of genetic factors in the formation of disease is now considered limited $(65,66)$. Known or suspected mutated familial ALS genes are SOD1, TARDBP, C9ORF72, FUS, ANG, OPTN, SETX, and SQSTM1 (64). Other mutated genes not associated with familial $A L S$ are listed as $T B K 1$ (67), A TXN2 (68), C21ORF2 (69), ITPR2 (70), NEK1 (71), and duplicated $S M N 1$ (72).

According to the results of a meta-analysis conducted in 2017 that evaluated 111 studies, mutated genes associated with ALS were found at a rate of $47.7 \%$ in patients with familial ALS and $5.2 \%$ in patients with sporadic ALS (73). The frequency of major $A L S$ gene mutations is significantly different between European and Asian patients. The most common gene mutation in Europe, C9ORF72, is found in $33.7 \%$ of patients with familial ALS, whereas it is found in $5.1 \%$ of patients with sporadic ALS. This mutation is followed by SOD1 (14.8\% of familial patients, $1.2 \%$ of sporadic patients), TARDBP(4.2\% of familial patients, $0.8 \%$ of sporadic patients), and FUS mutations (2.8\% of familial patients, and $0.3 \%$ of sporadic patients). In contrast, the most common gene mutation in Asia is SOD1 (30\% of familial patients, 1.5\% of sporadic patients), followed by FUS (6.4\% of familial patients, $0.9 \%$ of sporadic patients), and C9ORF72 (2\% of familial patients, $0.3 \%$ of sporadic patients) and TARDBP mutations $(1.5 \%$ of familial patients, $0.2 \%$ of sporadic patients). In this regard, in a study conducted in Turkey (Figure 2), C9ORF72 was found in $18.0 \%$ of familial patients, SOD1 gene mutation in $12.2 \%$, FUS in $5.0 \%, T A R D B P$ in $3.7 \%$, and UBQLN2 in $2.4 \%$, and no gene mutation was found in approximately $40 \%$ of familial patients in total (74). On the other hand, C9ORF72 is found in $3.1 \%$ of sporadic patients, and with the addition of others, there is a mutation rate of $3.7 \%$ in total in sporadic patients (74).

At this point, it is worth mentioning that $5 \%$ to $10 \%$ of patients with ALS are familial and the rest are sporadic (idiopathic) patients.

\section{Life Expectancy and Prognosis}

Life expectancy in ALS varies depending on the presence of different parameters. Up to $10 \%$ of patients with ALS have a slow course and live ten years or more. However, the majority of patients have a much more limited life expectancy after diagnosis. Recent studies reported that the mean or median life expectancy ranged

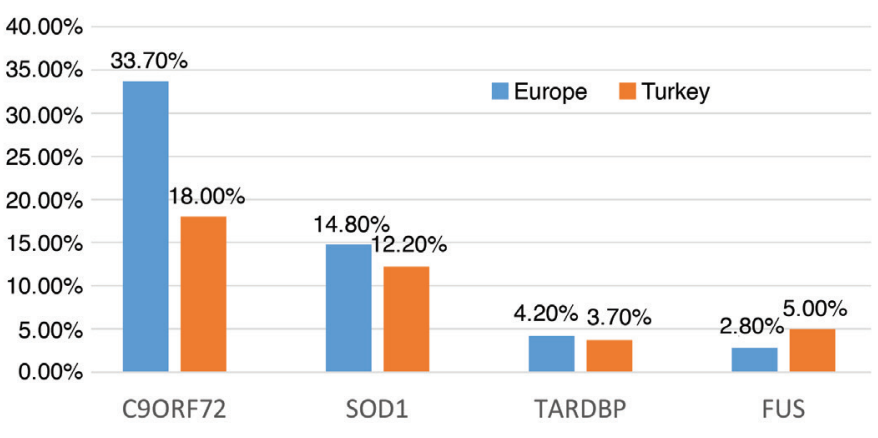

Figure 2. Gene mutation frequency in patients with familial ALS in Europe and Turkey $(73,74)$.

ALS: Amyotrophic lateral sclerosis 
between 24 and 50 months, beginning from the onset of symptoms to death or invasive respiratory support $(3,5,6,23,25,26,28,29,30$, $46,50)$. This period is around 24 months in Northern Europe and 30 months in Western and Southern Europe (75). Life expectancy is longer in North America, but the longest reports have come from Asia. Especially in Iran, this period extends up to 48 months (75). In addition to death, tracheostomy is also considered an endpoint in calculations. Performing tracheostomy significantly prolongs the life span of patients with ALS. A study conducted in Norway showed that the average life span from the onset of symptoms to death in patients who underwent tracheostomy was 5 years longer than patients who did not undergo tracheostomy (5).

Many factors can be mentioned that prolong life, one of which is male sex (9). Another is the site of onset of the disease. Patients with spinal-onset have a longer life expectancy than those with bulbar-onset $(3,5,7,9,25,76)$. The time to death is later in patients who are diagnosed at a younger age and whose symptoms begin at an early age $(25,51)$. Another influencing factor is the score obtained from the ALS Functional Rating scale. If this score is high, the life expectancy is longer (76). Again, gaining weight after diagnosis is a factor that prolongs the life span (46). However, a decrease of two units or more in BMI within six months after diagnosis decreases the life span (77).

Analysis of data from community-based prospective registries shows that mortality rates vary between $22.0 \%$ and $34.1 \%$ within one year after diagnosis $(77,78)$. Causes of death in the first year are generally respiratory failure, pneumonia, cardiovascular causes, cachexia, and marasmus (77).

The presence of concomitant diseases involving the respiratory system and the genitourinary system (20), the presence of cognitive impairment or depression (23), and the presence of highdensity organic contaminants (polybrominated diphenyl ethers, polychlorinated biphenyls, and the like) in plasma (27) are factors that negatively affect life expectancy.

\section{Mortality}

When deaths caused by motor neuron diseases are examined, it is seen that more than half of all deaths globally originate from three regions. These regions are North America, Western Europe, and Australasia (Australia, New Zealand, New Guinea and nearby islands) (21). All deaths in the rest of the world are fewer than in these three regions. According to estimates made by the Global Burden of Disease, Motor Neuron Disease Collaborators Group, using the Bayesian meta-regression model, there were 330,918 patients with motor neuron disease in 2016 (prevalence, 4.5 per hundred thousand), and the number of new patients was estimated as 57,452 (incidence, 0.78/100,000 person-year), and 34,325 deaths were detected (mortality rate, $0.46 / 100,000$ person-year) (21). Worldwide, age-standardized ALS mortality rates increased by around 8\% between 1990 and 2016 (21). This increase was statistically significant in all other groups except those with low socioeconomic index. In a study covering the years 2011-2014 in the USA, the ALS mortality rate standardized by age based on the USA 2000 population structure was found as 1.7/100,000 [95\% confidence interval (CI): 1.68-1.72] (79). This rate was 2.09 (95\% CI: 2.05-2.12) in men and 1.37 (95\% CI: 1.35-1.40) in women (79). The situation against male sex in the disease rates continues similarly in the mortality rates.
Some studies conducted in different countries suggested that mortality rates tended to decrease from the north and west regions to the south and east regions. For example, a study examining 105,000 ALS deaths, in which the diagnoses were made based on death certificates in 30 years (1969-1998) in the USA found a decreasing trend in ALS deaths from the north-west regions to the south-east (80). It has been suggested that this change may be due to the genetic risks of ALS due to the changing ethnic differentiation from the north-west to the south-east and the spread of mixed population structure. On the other hand, a clinical-based study based on hospital records conducted in Sweden in recent years mentioned a statistically insignificant reduction trend in ALS risk from north to south (81). Related with this, a 15-year study examining 9,500 ALS deaths in Spain found a reduction in mortality from north to south (82). This decreasing trend in both incidence and mortality rates from north to south in different geographic areas is also seen when the global data of the disease are examined. As mentioned earlier, the disease is significantly more common and causes death in North and West Europe, North America, compared with South and East Asia. To enlighten this issue, which is generally tried to be explained by genetic reasons, further studies involving different geographic regions are required.

\section{Geographical Foci of ALS in the World}

The West Pacific form of ALS, which has a geographic feature, has been reported as 50-100 times higher than the different geographic regions of the world (83). However, the reasons for this focus have not been clearly explained. In the last century, in the early 1950s, the incidence of ALS in Guam Island reached the highest level in the world, approaching 100/100,000 thousand (person-year) (84). Since the 1960s, the incidence of ALS dropped dramatically (3 person-years/100,000), approaching the rates of Europe or North America $(83,84)$. The incidence of parkinsonismdementia complex (PDC), which was another disease phenotype, reached 60/100,000 (person-years) in this region in the early 1960 s, and then decreased to $10 / 100,000$ in the 1980 s.

Another focus of the disease is the Kii Peninsula in Japan (85). Both forms of the disease are present in this region and are closely related and are referred to as ALS-PDC (86). Although the incidence of both phenotypes in Kii decreased significantly, similar to Guam, the incidence of PDC increased slightly in the 1980s and 1990s (87).

New Guinea, another focus of the disease, still has high prevalence and incidence rates of ALS and PDC, despite declining over time (88). In this region, it is estimated that the prevalence of ALS is at least 73/100,000 and the prevalence of PDC is around 53/100,000 (89).

The reason for the high disease incidence and prevalence in these regions is still not fully understood. The disparity was initially explained genetically due to ethnic groups living in these areas and having the disease (Chamorros in Guam and Rota, Japanese residents in the Kii peninsula and Honshu, Auyu and Jakai-speaking tribes on New Guinea Island in West Papua). Although they were studied $(90,91)$, rapid decreases in incidence in a short time suggested that genetic explanations alone would be insufficient and some characteristics such as environmental or lifestyle and dietary habits would be more prominent in these isolated groups (92). This sudden decline in incidence may be due to the disappearance of an unknown and disease- 
related exposure, especially in Guam and neighboring regions, which are undergoing a rapid Westernization process in terms of lifestyle. According to the most discussed hypothesis, the seeds of the plant called cycas circinalis (cycad), which grew only in this region, were widely used in the traditional Chamorro diet in the 1950 s and 1960s (93). These seeds contain a cyanobacterial neurotoxin ( $\beta$-N-methylamino-L-alanine). It is suggested that the effect of this toxin, which is thought to affect nerve cells, has disappeared and the incidence of disease has decreased, especially with the rapid change of traditional dietary habits in Guam. Another theory is that the people of the region consume a local species of bat (Flying Fox) as food. This bat feeds on cycad and contains high doses of neurotoxin. This hypothesis is supported by the decrease in the incidence of ALS-PDC in Guam in parallel with the rapid disappearance of the bat population in the region (94).

The currently agreed view is that both genetic and environmental factors play a role in the Western Pacific foci.

\section{Global Disease Burden and Reflection to the Future}

The Global Burden of Disease Project aims to determine the burden of diseases and injuries globally and in individual countries using a standardized protocol and the same measurement methods. While evaluating the total burden of the disease, besides deaths, the limitations caused by the disability of the disease are also taken into consideration. One criterion used for this assessment is Disability Adjusted Life Year (DALY). DALY is the sum of years lived with disability caused by illness and the resultant of the years that death due to disease takes from the average expected life expectancy. While calculating the Global Disease Burden, all data belonging to the countries are collected and the missing data are attempted to be completed and estimated with advanced statistical methods (95).

In the Global Disease Burden, ALS is examined in the category of motor neuron diseases and other rare motor neuron disorders. According to the latest Global Burden of Disease data, there were 331,000 prevalent cases and 58,000 new incident cases worldwide in 2016 (95). The number of years lost or experienced with disability (DALY) caused by this disease group in 2015 was around 910,000 years (96).
When we evaluate the disease and death rates observed so far, it is seen that 0.6 to 3.8 patients/100,000 population are added to the disease pool every year. The prevalence of the disease is between 4.1 and 8.4/100,000. The increasing incidence and prolonging lifespan over the years will further increase the prevalence burden. In addition, the prediction of the mortality rate as $0.46-$ $1.7 / 100,000$ and the fact that the incidence rates are above the mortality rates suggest that the prevalence pool will gradually rise and the disease burden will increase for an unpredictable period.

Age-specific ALS incidences increase with age, reaching the highest value in the 65-75 age range, and it tends to decrease from the age of 75 first in men and then in women (17). When the life expectancy is examined, the life expectancy in many regions with high population density (South and East Asia, Africa, South America) has not reached these ages as of now, but there is a rapid aging process in societies. In the near future, the age distribution of the population in these regions will develop in a similar direction to the countries of Northern Europe and North America. This will mean a significant population increase in the age group with a high risk of developing ALS and will cause an increase in the crude incidence and prevalence rates of ALS. A recent study of ten regions (China, Europe, Iran, Japan, Libya, New Zealand, Serbia, Taiwan, the USA, and Uruguay) and data covering $34 \%$ of the world's population predicted future changes in ALS prevalence (97). These estimates are presented in Table 4.

When the incidence rates in these countries are reflected in the continental populations where they are located, it is predicted that the 222,801 patients present in 2015 will reach 376,674 in 2040 (97). This increase will be largely due to the aging of the world population. As of today, the population at risk of ALS in underdeveloped and developing countries is proportionally lower than in developed countries. When the age structure of the world population was examined by years, the proportion of the population aged over 60 years was $8 \%$ in 1950 , and reached $12 \%$ in 2013. Estimates for 2050 show that this ratio will reach $21 \%$. In the underdeveloped and developing countries that accommodated the majority of the world's population, the rate of the population over 60 years old was $6 \%$ in 1950, and reached $9 \%$ in 2013. In 2050, this ratio will reach $19 \%$ (98). These countries have the lowest incidence of ALS today, and the population at risk of disease will increase significantly by 2050 .

Table 4. Current number of patients with amyotrophic lateral sclerosis in 2015 and 2040 (expected) across ten geographic regions

\begin{tabular}{lccc} 
Region & Year-2015 & Year-2040 & Increase in the number of patients $\%$ \\
Libya & 293 & 635 & 116.7 \\
USA & 21.835 & 29.306 & 34.2 \\
Uruguay & 207 & 269 & 30.0 \\
China & 20.329 & 29.734 & 46.3 \\
Iran & 1.409 & 2.992 & 112.3 \\
Japan & 5.866 & 6.431 & 9.6 \\
Taiwan & 622 & 796 & 28.0 \\
Europe & 29.208 & 35.024 & 19.9 \\
Serbia & 126 & 117 & -7.1 \\
New Zealand & 265 & 391 & 47.5 \\
\hline
\end{tabular}


This increase is expected to be reflected in the ALS disease burden. Therefore, the increase in the number of current patients with ALS will be much faster in the developing world than in the developed world. In the next 25 years, the largest increase in the number of patients with ALS will occur in Africa with an increase of $116 \%$. This continent will be followed by Asia with $81 \%$ and South America with 73\% (97). Initially, it can be predicted that the increase in incidence in developing countries is higher than the prevalence, with the expectation that adequate care opportunities in health services are limited and early deaths are frequent. However, over time, with increasing care opportunities and life expectancy, the prevalence of the disease will increase significantly.

\section{Situation in Turkey}

ALS has entered as a new interest in research area in Turkey. There was a study performed in Thrace on this subject that was completed and published (7). A new study has just been completed by Uysal et al. (99) in Antalya and is in the process of being published. According to the research conducted in Thrace, the incidence of ALS was found as 1.9/100,000 and the point prevalence was found as 7.3. The rates were located at a level between East Asia and North Europe-America worldwide. Although the data of the study conducted in Antalya were similar to these findings, the incidence $(1.4 / 100,000)$ was lower than in Thrace. A declining trend in incidence and mortality rates was detected in different regions from north to south $(80,81,82)$, yet despite the data being very early and insufficient, they are interesting for Turkey $(7,99)$. Also in the Thrace study, the mean age at diagnosis was 57 years, the male/female ratio was $1.8,22.1 \%$ of the patients had bulbar onset, and $77.9 \%$ of the patients had spinal onset (7). The average age at diagnosis in Antalya was 58.2 years, the male/female ratio was 2.0 , the bulbar onset rate was $18.3 \%$, and the spinal onset rate was $81.7 \%$ (99). The average delay in diagnosis from the beginning was 12 months. These findings demonstrate compliance with the links established between ALS and Turkey's geographic location, socio-economic status, and population structure.

Turkey is a developing country. According to the results of the Address-Based Population Registration System, the population over the age of 60 years was around $10,595,000$ in 2018, making up $12.9 \%$ of the total population. In the reflections of the same data for 2060, it is estimated that the population aged over 60 years will reach around $30,722,000$ and its ratio in the total population will be $28.6 \%$ (100). This increase indicates that there will be a significant increase in the number of people at risk of ALS and that there will be a significant increase in the number of patients with ALS in Turkey in the coming years.

\section{Conclusion}

Although ALS is included in the group of rare diseases, it is a disease that puts both patients and their relatives in difficult situations due to the severity of the disability and obstacles caused by the disease, its continuous progression, the difficulty of patient care, and the resulting death. Despite the large number of studies on ALS, its rarity restricts studies on causal analysis. The low number of patients is the greatest problem. Most studies are focused on Europe and North America. Healthy data on this issue cannot be obtained from many settlements in the world. If we compare our epidemiologic knowledge of the disease with the life of a human being, ALS is like a newly talking child. For this reason, there is a need to conduct epidemiologic studies in regions of the world that are in the dark in terms of information about ALS with standardized diagnostic applications based on the same criteria, and to create an infrastructure that will allow data to be gathered in regions such as Europe and North America, to establish recording systems, and to conduct analytical-causal analyses. Reflecting the world population to the future shows that underdeveloped and developed countries will age rapidly, and parallel to this, the burden of chronic and degenerative diseases including ALS will increase significantly. It is vital to produce information that will prepare the ground for the necessary planning in order to alleviate this burden.

\section{Ethics}

Peer-review: Externally and internally peer-reviewed.

\section{Authorship Contributions}

Concept: M.R.A., H.U., Literature Search: M.R.A., H.U., Writing: M.R.A.

Conflict of Interest: No conflict of interest was declared by the authors.

Financial Disclosure: The authors declared that this study received no financial support.

\section{References}

1. Kumar RD, Aslinia F, Yale SH, Mazza JJ. Jean-Martin Charcot: The father of neurology. Clin Med Res 2011;1:46-49.

2. Brennan F. The 70th Anniversary of the Death of Lou Gehrig, Am J Hosp Palliat Care 2012; 29:512-514.

3. Longinetti E, Wallin AR, Samuelson K et al. The Swedish motor neuron disease quality registry. Amyotroph Lateral Scler Frontotemporal Degener 2018;19:528-537.

4. Palese F, Sartori A, Veriello L, et al. Epidemiology of amyotrophic lateral sclerosis in Friuli-Venezia Giulia, North-Eastern Italy, 2002 2014: a retrospective population based study. Amyotroph Lateral Scler Frontotemporal Degener 2019;20:90-99.

5. Benjaminsen E, Alstadhaug KB, Gulsvik M, Baloch FK, Odeh F. Amyotrophic lateral sclerosis in Nordland County, Norway, 2000-2015:prevalence, incidence, and clinical features. Amyotroph Lateral Scler Frontotemporal Degener 2018;19:522-527.

6. Jun KY, Park J, Oh KW, et al. Epidemiology of ALS in Korea using nationwide big data. J Neurol Neurosurg Psychiatry 2019;90:395-403.

7. Turgut N, Birgili O, Varol Saracoglu G, et al. An epidemiologic investigation of amyotrophic lateral sclerosis in Thrace, Turkey, 2006-2010. Amyotroph Lateral Scler Frontotemporal Degener 2019;20:100-106.

8. Zhou S, Zhou Y, Qian S, et al. Amyotrophic lateral sclerosis in Bejing: epidemiologic features and prognosis from 2010 to 2015. Brain Behav 2018;8:e01131.

9. Leighton DJ, Newton J, Stephenson LJ, et al. Changing epidemiology of motor neurone diseases in Scotland. J Neurol 2019;266:817-825.

10. Rose L, McCim D, Lease D, et al. Trends in incidence, prevalence, and mortality of neuromusculer disease in Ontario, Canada: a population-based retrospective cohort study (2003-3014). PLoS One 2019;14:e0210574. Available from: URL: doi:10.1371/journal.pone.0210574. Accessed date: 24.03.2020.

11. Longinetti E, Fang F. Epidemiology of amyotrophic lateral sclerosis, an update of recent literatüre. Curr Opin Neurol 2019;32:771-776.

12. Logroscino G, Piccininni M. Amyotrophic Lateral Sclerosis Descriptive Epidemiology: The Origin of Geographic Difference. Neuroepidemiology 2019;52:93-103.

13. Kim HJ, Oh KW, Kwon MJ, et al. Identification of mutations in Korean patients with amyotrophic sclerosis using multigene panel testing. Neurobiol Aging 2016;37:209. 
14. Kwon MJ, Baek W, Ki CS, et al. Screening of the SOD1, FUS, TARDBP, ANG and OPTN mutations in Korean patients with familial and sporadic ALS. Neurobiol Aging 2012;33:1017.

15. Logroscino G, Traynor BJ, Hardiman O, et al. Incidence of amyotrophic lateral sclerosis in Europe. J Neurol Neurosurg Psychiatry 2010;81:385-390.

16. Beghi E, Millul A, Micheli A, et al. Incidence of ALS in Lombardy, Italy Neurology 2007;68:141-145.

17. Marin B, Boumediene F, Logroscino G, et al. Variation in world-wide incidence of amyotrophic lateral sclerosis: a meta-analysis. Int J Epidemiol 2017;46:57-74.

18. Nelson LM, Topol B, Kaye W, et al. Estimation of the prevalence of amyotrophic lateral sclerosis in the United states using national admministrative health care data from 2002 to 2004 and capture-recapture methodology. Neuroepidemiology 2018;5:149-157.

19. Mehta P, Kaye W, Raymond J, et al. Prevalence of amyotrophic lateral sclerosis: United States. MMWR Morb Mortal Wkly Rep 2018;67:12851289.

20. Bhattacharya R, Harvey RA, Abraham K, Rosen J, Mehte P. Amyotrophic lateral sclerosis among patients with a Medicare Advantage prescription drug plan: prevalence, survival and patient characteristics. Amyotroph Lateral Scler Frontotemporal Degener 2019;20:251-259.

21. Logroscino G, Piccininni M, Benoit M, et al. GBD 2016 Motor Neuron Disease Collaborators. Global, regional, and national burden of motor neuron diseases 1990-2016: a systematic analysis for the Global Burden of Disease Study 2016. The Lancet Neurol 2018;17:1083-1097.

22. Ingre C, Roos PM, Piehl P, Kamel F, Fang F. Risk factors for amyotrophic lateral sclerosis. Clin Epidemiol 2015;7:181-193.

23. De Marchi F, Sarnelli MF, Solara V, et al. Depression and risk of cognitive disfunctions in amyotrophic lateral sclerosis. Acta Neurol Scand 2019;139:438-445.

24. Dickerson AS, Hansen J, Kioumourtzoglou MA, et al. Study of occupation and amyotrophic lateral sclerosis in a Danish cohort. Occup Environ Med 2018;75:630-638.

25. Dorst J, Chen L, Rosenbohm A, et al. Prognostic factors in ALS: a comparison between Germany and China. J Neurol 2019;266:1516-1525.

26. Luna J, Diagana M, Ait Aissa L, et al. Clinical features and prognosis of amyotrophic lateral sclerosis in Africa: the TROPALS study. J Neurol Neurosurg Psychiatry 2019;90:20-29.

27. Goutman SA, Boss J, Patterson A, et al. High plasma concentrations of organic pollutants negatively impact survival in amyotrophic lateral sclerosis. J Neurol Neurosurg Psychiatry 2019;90:907-912.

28. Hodkinson VL, Lounsberry J, Mirian A, et al. Provincial differences in the diagnosis and care of amyotropfic lateral sclerosis. Can J Neurol Sci 2018;45:652-659.

29. Moglia C, Calvo A, Grassano M, et al. Early weight loss in amyotrophic lateral sclerosis: outcome relevance and clinical correlates in a populatonbased cohort. J Neurol Neurosurg Psychiatry 2019;90:666-673.

30. Ryan M, Zaldivar Vaillant T, McLaughlin RL, et al. Comparison of the clinical and genetic features of amyotrophic lateral sclerosis across Cuban, Uruguayan, and Irish clinic-based populations. J Neurol Neurosurg Psychiatry 2019;90:659-665.

31. Hardiman O, Al-Chalabi A, Brayne $\mathrm{C}$, et al. The changing picture of amyotrophic lateral sclerosis: lessons from European registers. J Neurol Neurosurg Psychiatry 2017;88:557-563.

32. Li TM, Alberman E, Swash M. Comparison of sporadic and familial disease amongst 580 cases of motor neuron disease. J Neurol Neurosurg Psychiatry 1988;51:778-784.

33. Camu W, Khoris J, Moulard B, et al. Genetics of familial ALS and concequences for diagnosis: French ALS Research Group. J Neurol Sci 1999; 165:21-26

34. Logroscino G, Marin B, Piccini M, et al. Referral Bias in ALS epidemiological studies. PLoS One 2018;13:e0195821.

35. Mehta PR, Jones AR, Opie-Martin S, et al. Younger age of onset in familial amyotrophic lateral sclerosis is a result of pathogenic gene variants, rather than ascertainment bias. J Neurol Neurosurg Psychiatry 2019;90:268-271.

36. Byrne S, Bede P, Elamin M, et al. Proposed criteria for familial amyotrophic lateral sclerosis. Amyotroph Lateral Scler 2011;12:157-159.

37. Marin B, Fontana A, Arcuti S, et al. Age-specific ALS incidence: a doseresponse meta-analysis. Eur J Epidemiol 2018;33:621-634
38. Murphy NA, Arthur KC, Tienari PJ, et al. Age-related penentrance of the C9orf72 repeat expansion. Sci Rep 2017;7:2116.

39. Pliner HA, Mann DM, Traynor BJ. Searching for Grendel:origin and global spread of the C9ORF72 repeat expantion. Acta Neuropathol 2014;127:391396.

40. Konno T, Shiga A, Tsujino A, et al. Japanese amyotrophic lateral sclerosis patients with GGGGCC hexanucleotide repeat expansion in C9ORF72. J Neurol Neurosurg Psychiatry 2013;84:398-401.

41. Alavi A, Nafissi S, Rohani M, et al. Repeat expantion in C9ORF72 is not a major cause of amyotrophic lateral sclerosis among Iranian patients. Neurobiol Aging 2014;35:267.e1-7. doi:10.1016/j.neurobiolaging.2013.07.016.

42. Murros K, Fogelholm R. Amyotrophic lateral sclerosis in Middle-Finland: an epidemiological study. Acta Neurol Scand 1983;67:41-47.

43. Agrawal M, Biswas A. Molecular diagnostics of neurodegenerative disorders Front Mol Biosci 2015;2:54.

44. Brooks BR, Miller RG, Swash M, Munsat TL, World Federation of Neurology Research Group on Motor Neuron Diseases. El Escorial revisited: revised criteria for the diagnosis of amyotrophic lateral sclerosis. Amyotroph Lateral Scler Other Motor Neuron Disord 2000;1:293-299.

45. Pupillo E, Bianchi E, Chio A, et al. Amyotrophic lateral sclerosis and food intake. Amyotroph Lateral Scler Frontotemporal Degener 2018;19:267274 .

46. Shimizu T, Nakayama Y, Matsuda C, et al. Prognostic significance of body weight variation after diagnosis in ALS: a single-center prospective cohort study. J Neurol 2019;266:1412-1420.

47. Knibb JA, Keren N, Kulka A, et al. A clinical tool for predicting survival in ALS. J Neurol Neurosurg Psychiatry 2016;87:1361-1367.

48. Haverkamp LJ, Appel V, Appel SH. Naturel history of amyotrophic lateral sclerosis in a database population. Validation of a scoringsystem and a model for survival prediction. Brain 1995;118:707-719.

49. Forbes RB, Colville S, Swingler RJ, Scottish ALS/MND Register. The epidemiology of amyotrophic lateral sclerosis (ALS/MND) in people aged 80 or over. Age Ageing 2004;33:131-134.

50. Qadri S, Langefeld CD, Milligan C, Caress JB, Cartwright MS. Racial differences intervention rates in individuals with ALS: a case-control study. Neurology 2019;92:e1969-e1974.

51. Karanevich AG, Weisbrod LJ, Jawdat O, et al. Using automated electronic medical record data extraction to model ALS survival and progresion. BMC Neurol 2018;18:205.

52. D'Ovidio F, Rooney JP, Visser AE, et al. Association between alcohol exposure and the risk of amyotrophic lateral sclerosis in the Euro-MOTOR study. J Neurol Neurosurg Psychiatry 2019;90:11-19.

53. de Carhalvo M, Matias T, Coelho F, et al. Motor neuron disease presenting with respiratory failure. J Neurol Sci 1996;139:117-122.

54. Chen R, Grand'Maison F, Strong MJ, Ramsay DA, Bolton CF. Motor neuron disease presenting as acute respiratory failure: a clinical and pathological study. J Neurol Neurosurg Psychiatry 1996;60:455-458.

55. Armon C. Smoking may be considered an established risk factor for sporadic ALS. Neurology 2009;73:1693-1698.

56. Gallo V, Bueno-De Mesquita HB, Vermeulen R, et al. Smoking and risk for amyotrophic lateral sclerosis: analysis of the EPIC cohort. Ann Neurol 2009; 65:378-385.

57. Zhan Y, Fhang F. Smoking and amyotrophic lateral sclerosis: A mendelian randomization study, Ann Neurol 2019;85:482-484.

58. Bandres-Ciga S, Noyce AJ, Hemani G, et al. Shared polygenic risk and causal inferences in amyotrophic lateral sclerosis. Ann Neurol 2019;85:470481.

59. Couratier P, Corcia P, Lautrette G, et al. Epidemiology of amyotrophic lateral sclerosis: a review of literature. Rev Neurol 2016;172:37-45.

60. Belbasis L, Bellou V, Evangelou E. Environmental risk factors and amyotrophic lateral sclerosis: an umbrella review and critical assessment of current evidence from systematic reviews and meta-analyses of observational studies. Neuroepidemiology 2016;46:96-105.

61. Hardiman O, Al-Chalabi A, Chio A, et al. Amyotrophic lateral sclerosis. Nat Rev Dis Primers 2017;3:17071

62. Zeng P, Zhou X. Causal effects of blood lipids on amyotrophic lateral sclerosis: a Mendelian randomization study. Human Mol Genet 2019;28:688-697.

63. Aberg M, Nyberg J, Robertson J, et al. Risk factors in Swedish young men for amyotrophic lateral sclerosis in adulthood. J Neurol 2018;265:460-470. 
64. Leblond CS, Kaneb HM, Dion PA, Rouleau GA. Dissection of genetic factors associated with amyotrophic lateral sclerosis. Exp Neurol 2014;262 Pt B:91-101.

65. Renton AE, Chio A, Traynor BJ. State of play in amyotrophic lateral sclerosis genetics. Nat Neurosci 2014;17:17-23.

66. Andersen PM, Al-Chalabi A. Clinical genetics of amyotrophic lateral sclerosis: what do we really know? Nat Rev Neurol 2011;7:603-615.

67. Cirulli ET, Lasseigne BN, Petrovski S, et al. Exome sequencing in amyotrophic lateral sclerosis identifies risk genes and pathways. Science 2015;347:1436-1441.

68. Lattante S, Conte A, Zollino M, et al. Contribution of major amyotrophic lateral sclerosis genes to the etiology of sporadic disease. Neurology 2012;79:66-72.

69. van Rheenen W, Ahatunov A, Dekker AM, et al. Genome-wide association analyses identify new risk variants and the genetic architecture of amyotrophic lateral sclerosis. Nat Genet 2016;48-1043-1048.

70. van Es MA, Van Vught PW, Blauw HM, et al. ITPR2 as a susceptibility gene in sporadic amyotrophic lateral sclerosis: a genom-wide association study. Lancet Neurol 2007;6:869-877.

71. Kenna KP, van Doormal PT, Dekker AM, et al. NEK1 variants confer susceptibility to amyotrphic lateral sclerosis. Nat genet 2016;48:10371042 .

72. Wang XB, Cui NH, Gao JJ, Qiu XP, Zheng F. SMN1 duplications contribute to sporadic amyotrophic lateral sclerosis susceptibility: evidence from a meta-analysis. J Neurol Sci 2014;340:63-68.

73. Zou ZY, Zhou ZR, Che CH, et al. Genetic epidemiology of amyotrophic lateral sclerosis: a systematic review and meta-analysis. J Neurol Neurosurg Psychiatry 2017;88:540-549.

74. Özoğuz A, Uyan Ö, Birdal G, et al. The distinct genetic pattern of ALS in Turkey and novel mutations. Neurobiol Aging 2015;36:1764.e9-1764.e18

75. Marin B, Logroscino G, Boumediene F, et al. Clinical and demographic factors and outcome of amyotrophic lateral sclerosis in relation to population ancestral origin. Eur J Epidemiol 2016;31:229-245.

76. Korner S, Kammeyer J, Zapf A, et al. Influence of environment and lifestyle on incidence and progress of amyotrophic lateral sclerosis in a German ALS population. Aging Dis 2019;10:205-216.

77. Wolf J, Safer A, Wöhrle CJ, et al. Factors predicting one-year mortality in amyotrophic lateral sclerosis patients - data from a population - based registry. BMC Neurol 2014;14:197.

78. Millul A, Beghi E, Logroscino G, et al. Survival of patients with amyotrophic lateral sclerosis in a population-based registry. Neuroepidemiology 2005;25:114-119.

79. Larson TC, Kaye W, Mehta P, Horton DK. Amyotrophic lateral sclerosis mortality in the United States, 2011-2014. Neuroepidemiology 2018;51:96-103.

80. Noonan CW, White MC, Thurman D, Wong LY. Temporal and geographic variation in United States motor neuron disease mortality, 1969-1998. Neurology 2005;64:1215-1221.

81. Fang F, Valdimarsdottir U, Bellocco R, et al. Amyotrophic lateral sclerosis in Sweeden,1991-2005. Arch Neurol 2009;66:515-519.

82. Alonso V, Villaverde-Hueso A, Hens MJ, et al. Increase in motor neuron disease mortality in Spain: temporal and geographical analysis (1990-2005). Amyotroph Lateral Scler 2011;12:192-198.

83. Steele JC, McGeer PL. The ALS /PDC syndrome of Guam and the cycad hypothesis. Neurology 2008;70:1984-1990.
84. Plato CC, Garruto RM, Galasko D, et al. Amyotrophic lateral sclerosis and parkinsonism-dementia complex of Guam: changing incidence rates during the past 60 years. Am J Epidemiol 2003;157:149-157.

85. Mimuro M, Yoshida M, Kuzuhara S, Kokuba Y. Amyotrophic lateral sclerosis and Parkinsonsonism-dementia complex of the Hohara focus of the Kii peninsula: a multiple proteinopathy? Neuropathology 2018;38:98-107.

86. Maragakis NJ, Galvez-Jimenez N. Epidemiology and pathogenesis of amyotrophic lateral sclerosis. Official reprint from UpToDate. www. uptodate.com (C) 2020

87. Kuzuhara S, Kokubo Y. Atypical parkinsonism of Japan: amyotrophic lateral sclerosis-parkinsonism-dementia complex of the Kii peninsula of Japan (Muro disease):an update. Mov Disord 2005;20:108-113.

88. Spencer PS, Palmer VS, Ludolph AC. On the decline and etiology of highincidence motor system disease in West Papua (southwest New Guinea). Mov Disord 2005;20:119-126.

89. Okumiya K, Wada T, Fujisawa M, et al. Amyotrophic lateral sclerosis and parkinsonism in Papua, Indonesia:2001-2012 survey results. BMJ Open 2014; 4:e004353.

90. Steele JC, Guella I, Szu-Tu C, et al. Defining neurodegeneration on Guam by targeted genomic sequencing. Ann Neurol 2015;77:458-468.

91. Dombroski BA, Galasko DR, Mata IF, et al. C9orf72 hexanucleotide repeat expansion and Guam amyotrophic lateral sclerosis-parkinsonism-dementia complex. JAMA Neurol 2013;70:742-745.

92. Spencer PS, Palmer VS, Kisby GE. Seeking environmental causes of neurodegenerative disease and envisioning primary prevention. Neurotoxicology 2016;56:269-283.

93. Cox PA, Davis DA, Mash DC, Metcalf JS, Banack SA. Dietary exposure to an environmental toxin triggers neurofibrillary tangles and amyloid deposits in the brain. Proc Biol Sci 2016;283:20152397.

94. Cox PA, Sacks OW. Cycad neurotoxins, consumption of flying foxes, and ALS-PDC disease in Guam. Neurology 2002;58:956-959.

95. GBD 2016 Disease and Injury Incidence and Prevalence Collaborators. Global, regional, and national incidence, prevalence, and years with disability for 328 diseases and injuries for 195 countries, 1990-2016: a systematic analysis for the Global Burden of Disease Study 2016. Lancet 2017;390:1211-1259.

96. Feigin VL, Abajobir AA, Amanuel A, et al. GBD 2015 Neurological Disorders Collaborator Group. Global, regional, and national burden of neurological disorders during 1990-2015:a systematic analysis for the Global Burden of Disease Study 2015. Lancet Neurol 2017;16:877-897.

97. Arthur KC, Calvo A, Price TR, et al. Projected increase in amyotrophic lateral sclerosis from 2015 to 2040. Nat Commun 2016;7:12408.

98. United Nations Department of Economic and Social Affairs / Population Division. World Population Ageing 2013 - ST/ESA/Ser.A/348. United Nations publication. New York; 2013.

99. Uysal H, Taghiyeva P, Türkay M, Köse F, Aktekin M. Amyotrophic lateral sclerosis in Antalya, Turkey. A prospective study, 2016-2018. Amyotroph Lateral Scler Frontotemporal Degener. 2020 Sep 12:1-7. doi: 10.1080/21678421.2020.1817089.

100. Türkiye İstatistik Kurumu (TUIK). Nüfus istatistikleri ve nüfus projeksiyonları. Erişim tarihi: 17/03/2020. Available from: htpp://www. tuik.gov.tr 